\title{
Effect of Hot Forging Pressure and Heat Treatment on CW625N Lead Free Brass Alloy Dezincification Resistance
}

\author{
S. ÖZHAN DOĞAN ${ }^{a, *}$ AND B. EKICI ${ }^{b}$ \\ ${ }^{a}$ Aktif Analiz Mühendislik San. Ve Tic. Ltd. Şti., Istanbul, Turkey \\ ${ }^{b}$ Marmara University Engineering Faculty, Göztepe, Istanbul, Turkey
}

\begin{abstract}
Brass alloys, like most materials, suffer from the inevitable effect of corrosion. The CW625N (CuZn35Pb1) alloy is called a lead-free alloy because it contains a maximum of $1.6 \% \mathrm{~Pb}$ in its composition. It is suitable for hot forging, and is a new type of alloy. In this study, CW625N brass alloy test samples were shaped by hot forging. Heat treatment of some of the formed test samples and the effect of these processes on hardness, microstructure, and dezincification resistance were investigated. Forging temperature was kept constant at $750{ }^{\circ} \mathrm{C}$ and forging pressure was 70 bar and 90 bar. The samples from the hot forging were cooled in calm air. A portion of the test samples cooled in calm air were heat treated at $550^{\circ} \mathrm{C}$ for $2.5 \mathrm{~h}$. The heat treated test samples were compared with the non-heat treated test samples. When the hardness values of the heat treated samples were examined, it was seen that they were harder than the non-heat treated samples. Metallographic examination showed that the grain sizes of the heat treated samples decreased and the dezincification resistance was high. When the microstructures were examined, it was seen that needle-shaped structures were formed in the samples which were forged under 90 bar and heat treated. Increase of forging pressure enhanced the hardness and the grain size. However, there were no direct effect on dezincification resistance.
\end{abstract}

DOI: 10.12693/APhysPolA.137.545

PACS/topics: brass, brass alloys, dezincification for brass

\section{Introduction}

Brass alloys contains $3-4 \%$ lead in conventional brass alloys. Use of lead in brass alloys has been restricted in potable water systems since 2014 due to increasing health concerns. However, determining the corrosionresistance potential of newer lead-free brasses is important [1]. The production of lead-free brass alloy with high dezincification resistance in the world is not large.

Industrial brasses include copper and zinc additions, as well as other alloying elements. This alloy family consists of copper, zinc and one or more additional elements (aluminum, tin, lead, nickel, manganese, iron, silicon, arsenic, antimony, and phosphorus). These additional alloying elements give the brass additional features. In this way, element addition improves the material's mechanical properties, corrosion resistance, castability, and workability. The change in properties depends on the element type and on its influence on the material structure [2] (Fig. 1).

Brass alloys mainly consist of copper and zinc elements. Over time, the zinc in the alloy undergoes corrosion and moves away from the alloy. This condition is called dezincification.

Lots of effort is made to produce CW625N alloys using the same processes as for other hot forged alloys. These processes consist of the following steps:

\footnotetext{
* corresponding author; e-mail: serap.ozhan@aktifanaliz.com.tr
}

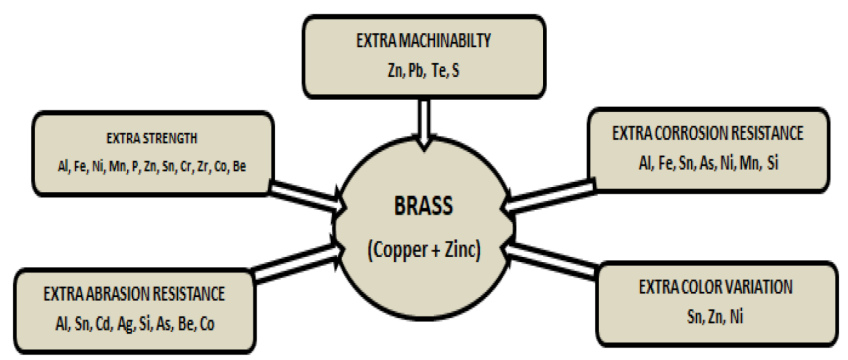

Fig. 1. Effects of added elements on brass.

obtaining the alloy in the composition range, producing rods by extrusion method, hot forging forming according to the desired geometry, cooling in calm air, heat treatment process, and machining applications for the final product $[3,4]$.

The intermediate heat treatment process is applied to increase the dezincification resistance of the alloy. However, this application is very expensive and also slows down the production process. It is also known that the heat treatment process is applied more than once in the production of industrial products.

\section{Experimental studies}

In this study, CW625N alloys with $37 \mathrm{~mm}$ diameter and $5.5 \mathrm{~m}$ long commercial grade bars were used. Standard chemical composition of CW625N is shown in Table I [5]. The bars were cut into pieces of $400 \mathrm{~mm}$ length. A total of 12 test samples were produced at forging temperature of $750{ }^{\circ} \mathrm{C}, 70 \mathrm{bar}$ and 90 bar for forging pressure. Each test parameter plan is given in Table II. 
TABLE I

Chemical composition of CW625N alloy according to CEN / TS 13388 standard [5].

\begin{tabular}{c|c|c|c|c|c}
\hline \hline Elements & $\mathrm{Cu}$ & $\mathrm{Pb}$ & $\mathrm{Sn}$ & $\mathrm{Fe}$ & $\mathrm{Ni}$ \\
\hline Min. \% & 62.00 & 1.2 & $\leq 0.3$ & $\leq 0.3$ & $\leq 0.2$ \\
Max. \% & 64.00 & 1.6 & & & \\
\hline \hline Elements & $\mathrm{Al}$ & $\mathrm{Mn}$ & $\mathrm{As}$ & $\mathrm{Zn}$ & Other \\
\hline Min. \% & $\leq 0.5$ & $\leq 0.1$ & 0.02 & diff. & $\leq 0.2$ \\
Max. \% & $\leq 0.7$ & & 0.15 & &
\end{tabular}

Hot forging parameter plan.

TABLE II

\begin{tabular}{c|c|c}
\hline \hline $\begin{array}{c}\text { Hot forming } \\
\text { temperature }\end{array}$ & $\begin{array}{c}70 \text { bar forging } \\
\text { pressure samples }\end{array}$ & $\begin{array}{c}90 \text { bar forging } \\
\text { pressure samples }\end{array}$ \\
\hline & $5070 \mathrm{~s} 0$ & $5090 \mathrm{~s} 0$ \\
& $5070 \mathrm{~s} 1$ & $5090 \mathrm{~s} 1$ \\
$750{ }^{\circ} \mathrm{C}$ & $5070 \mathrm{~s} 2$ & $5090 \mathrm{~s} 2$ \\
& $5070 \mathrm{~s} 3$ & $5090 \mathrm{~s} 3$ \\
& $5070 \mathrm{~s} 4$ & $5090 \mathrm{~s} 4$ \\
& $5070 \mathrm{~s} 5$ & $5090 \mathrm{~s} 5$
\end{tabular}

Farmbrass brand hydraulic press, capable of applying 400 ton pressing force, was used to produce samples in accordance with TS EN 12165 and TS EN 12420 standards $[6,7]$. The forged test samples are shown in Fig. 2.

Six of the twelve samples (samples 5070s0, 5070s1, $5070 \mathrm{~s} 2,5090 \mathrm{~s} 0,5090 \mathrm{~s} 1$, and 5090s2) were heat treated for $180 \mathrm{~min}$ and at $550^{\circ} \mathrm{C}$ by using AFC Holdcroft furnace.

The chemical composition values were obtained by spectral analysis of each cooled test sample. Spectral analysis was performed with Thermo Scientific Niton XL2 980 Goldo model apparatus. The results of the chemical composition are shown in Table III.

TESKON TIME TH-500 analogue manual measuring device was used for hardness measurement. The device can measure hardness up to $150 \mathrm{kgf}$. In HRB measurement, $1 / 16$ in ball was used. The test results are shown in Table IV.
Rockwell hardness method (tested by immersion) was used in hardness tests using static load. Measurements were made at three different points of each sample (Fig. 3).

The samples were examined at magnification of two hundred. It was studied for microstructures and grain sizes [9]. The results are shown in Tables V and VI.

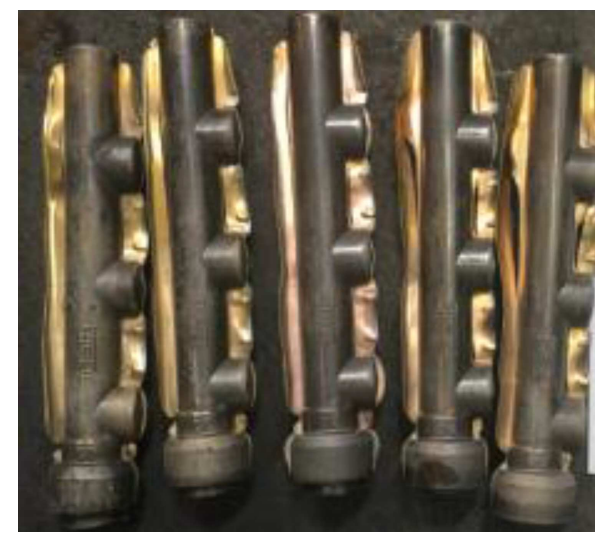

Fig. 2. Hot forged shaped test sample.

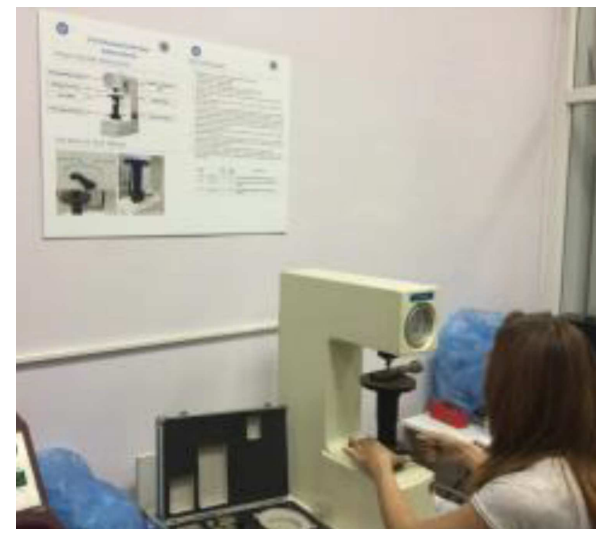

Fig. 3. Hardness measurement at Marmara University Mechanical Engineering Faculty laboratory.

Spectral analysis test results of samples.

TABLE III

\begin{tabular}{|c|c|c|c|c|c|c|c|c|}
\hline \multirow{2}{*}{$\begin{array}{c}\text { Sample } \\
\text { codes }\end{array}$} & \multicolumn{8}{|c|}{ Element [\%] } \\
\hline & $\mathrm{Fe}$ & $\mathrm{Si}$ & $\mathrm{Cu}$ & $\mathrm{Zn}$ & $\mathrm{Al}$ & $\mathrm{Sn}$ & $\mathrm{Pb}$ & Other \\
\hline $5070 \mathrm{~S} 0$ & 0.169 & 0.361 & 62.021 & 35.047 & 0.629 & 0.170 & 1.224 & 0.379 \\
\hline $5070 \mathrm{~S} 1$ & 0.179 & 0.360 & 62.018 & 35.029 & 0.632 & 0.169 & 1.231 & 0.382 \\
\hline $5070 \mathrm{~S} 2$ & 0.155 & 0.309 & 62.083 & 35.066 & 0.532 & 0.135 & 1.326 & 0.394 \\
\hline 5090S0 & 0.172 & 0.362 & 62.013 & 35.032 & 0.619 & 0.177 & 1.241 & 0.384 \\
\hline $5090 \mathrm{~S} 1$ & 0.170 & 0.363 & 62.024 & 35.041 & 0.621 & 0.166 & 1.230 & 0.385 \\
\hline $5090 \mathrm{~S} 2$ & 0.163 & 0.369 & 62.048 & 35.038 & 0.625 & 0.155 & 1.218 & 0.384 \\
\hline $5070 \mathrm{~S} 3$ & 0.172 & 0.366 & 62.041 & 35.043 & 0.613 & 0.172 & 1.210 & 0.383 \\
\hline $5070 \mathrm{~S} 4$ & 0.163 & 0.357 & 62.038 & 35.036 & 0.624 & 0.170 & 1.232 & 0.380 \\
\hline 5070 S5 & 0.169 & 0.360 & 62.037 & 35.028 & 0.625 & 0.167 & 1.233 & 0.381 \\
\hline $5090 \mathrm{~S} 3$ & 0.163 & 0.355 & 62.032 & 35.034 & 0.626 & 0.179 & 1.231 & 0.380 \\
\hline $5090 \mathrm{~S} 4$ & 0.179 & 0.359 & 62.034 & 35.031 & 0.622 & 0.166 & 1.229 & 0.380 \\
\hline 5090S5 & 0.174 & 0.354 & 62.034 & 35.037 & 0.621 & 0.164 & 1.233 & 0.383 \\
\hline
\end{tabular}


Hardness test results.

TABLE IV

\begin{tabular}{c|c|c|c|c}
\hline \hline \multirow{2}{*}{$\begin{array}{c}\text { Group } \\
\text { codes }\end{array}$} & \multicolumn{3}{|c|}{ Measurement $($ HRB $)$} & \multirow{2}{*}{ Average-1 } \\
\cline { 2 - 4 } & 1 & 2 & 3 & \\
\hline $5070 \mathrm{~s} 0$ & 42.4 & 42.9 & 43.6 & 42.97 \\
$5070 \mathrm{~s} 1$ & 42.6 & 43.3 & 43.8 & 43.23 \\
$5070 \mathrm{~s} 2$ & 42.8 & 43.3 & 43.8 & 43.30 \\
$5090 \mathrm{~s} 0$ & 43.2 & 43.8 & 44.5 & 43.83 \\
$5090 \mathrm{~s} 1$ & 43 & 43.7 & 44.4 & 43.70 \\
$5090 \mathrm{~s} 2$ & 42.8 & 43.5 & 44.3 & 43.53 \\
$5070 \mathrm{~S} 3$ & 32.5 & 33.1 & 33.8 & 33.13 \\
$5070 \mathrm{~S} 4$ & 32.2 & 32.7 & 33.5 & 32.80 \\
$5070 \mathrm{~S} 5$ & 32.1 & 32.8 & 33.6 & 32.83 \\
$5090 \mathrm{~S} 3$ & 33 & 33.6 & 34.3 & 33.63 \\
$5090 \mathrm{~S} 4$ & 33.1 & 33.8 & 34.6 & 33.83 \\
$5090 \mathrm{~S} 5$ & 32.8 & 33.5 & 34.2 & 33.50
\end{tabular}

TABLE V

Measured grain sizes $(10 \times 0.30)$ in microstructure perpendicular and parallel to the direction of extrusion.

\begin{tabular}{c|c|c|c|c}
\hline \hline \multirow{2}{*}{$\begin{array}{c}\text { Group } \\
\text { codes }\end{array}$} & \multicolumn{4}{|c}{ Grain size $(10 \times 0.30)[\mu \mathrm{m}]$} \\
\cline { 2 - 5 } & \multirow{2}{*}{ Perp. } & Par. & \multicolumn{2}{|c}{ Average } \\
\cline { 4 - 5 } & & 9 & & \\
\hline $5070 \mathrm{~S} 0$ & 9 & 9.5 & 9.34 & 9.50 \\
$5070 \mathrm{~S} 1$ & 9.5 & 9.5 & & \\
$5070 \mathrm{~S} 2$ & 9.5 & 10 & & \\
\hline $5090 \mathrm{~S} 0$ & 9.5 & 9.5 & & 9.84 \\
$5090 \mathrm{~S} 1$ & 9.5 & 10 & 9.67 & \\
$5090 \mathrm{~S} 2$ & 10 & 10 & & \\
\hline $5070 \mathrm{~S} 3$ & 13.5 & 14 & & \\
$5070 \mathrm{~S} 4$ & 13 & 13.5 & 13.34 & 13.84 \\
$5070 \mathrm{~S} 5$ & 13.5 & 14 & & \\
\hline $5090 \mathrm{~S} 3$ & 14 & 14.5 & & \\
$5090 \mathrm{~S} 4$ & 14.5 & 14.5 & 14.17 & 14.50 \\
$5090 \mathrm{~S} 5$ & 14 & 14.5 & &
\end{tabular}

Dezincification test results perpendicular

TABLE VI and parallel to the direction of extrusion.

\begin{tabular}{|c|c|c|c|c|}
\hline \multirow{3}{*}{$\begin{array}{c}\text { Group } \\
\text { codes }\end{array}$} & \multicolumn{4}{|c|}{ Dezincification depth $[\mu \mathrm{m}]$} \\
\hline & \multicolumn{2}{|c|}{$\begin{array}{c}\text { Perpendicular } \\
(\max . \text { tol. } 100 \mu \mathrm{m})\end{array}$} & \multicolumn{2}{|c|}{$\begin{array}{c}\text { Parallel } \\
(\max . \text { tol. } 200 \mu \mathrm{m})\end{array}$} \\
\hline & $\begin{array}{l}\text { Min. } \\
\text { value }\end{array}$ & $\begin{array}{l}\text { Max. } \\
\text { value }\end{array}$ & $\begin{array}{l}\text { Min. } \\
\text { value }\end{array}$ & $\begin{array}{l}\text { Max. } \\
\text { value }\end{array}$ \\
\hline $5070 \mathrm{~s} 0$ & 16.20 & 51.28 & 21.24 & 120.47 \\
\hline $5070 \mathrm{~s} 1$ & 14.35 & 64.37 & 18.63 & 132.65 \\
\hline $5070 \mathrm{~s} 2$ & 123.46 & 158.22 & 135.63 & 210.17 \\
\hline $5090 \mathrm{~s} 0$ & 45.14 & 72.58 & 40.61 & 117.23 \\
\hline $5090 \mathrm{~s} 1$ & 28.17 & 8046 & 35.72 & 96.28 \\
\hline $5090 \mathrm{~s} 2$ & 26.49 & 57.25 & 23.65 & 91.14 \\
\hline $5070 \mathrm{~s} 3$ & 84.56 & 144.37 & 92.50 & 251.28 \\
\hline 5070 s 4 & 88.33 & 140.26 & 135.41 & 234.67 \\
\hline $5070 \mathrm{~s} 5$ & 91.26 & 121.56 & 62.49 & 231.17 \\
\hline $5090 \mathrm{~s} 3$ & 72.29 & 131.71 & 97.56 & 242.48 \\
\hline $5090 \mathrm{~s} 4$ & 105.35 & 220.47 & 131.13 & 253.45 \\
\hline $5090 \mathrm{~s} 5$ & 64.51 & 99.83 & 128.34 & 247.48 \\
\hline
\end{tabular}

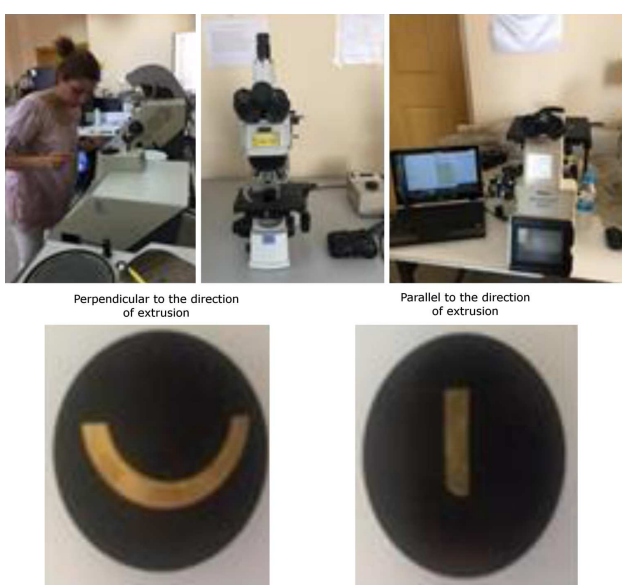

Fig. 4. Bakelite images of test samples [8].

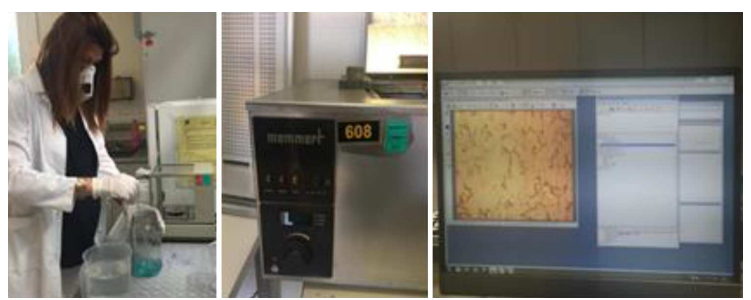

Fig. 5. Images of dezincification test stages.

Metallographic samples were prepared for examining microstructure. Sections, perpendicular and parallel to the direction of extrusion, were taken from each sample with Struers Labotom Discotom-5 brand cutting device. These sections were taken in bakelite. Bakelite images of test samples are shown in Fig. 4.

In order to look at the microstructure of the brass samples, sanding, polishing, and etching stages were made ready to be examined by microscope.

Dezincification depths should be examined in perpendicular and parallel to the direction of extrusion. According to TS EN ISO 6509-1 standard, the maximum dezincification depths should be $100 \mu \mathrm{m}$ and $200 \mu \mathrm{m}$, respectively $[9]$.

The samples were kept at $75^{\circ} \mathrm{C}$ in copper(ii) chloride dihydrate at $1 \%$ solution for $24 \mathrm{~h}$ in Nuve NB Water Bath device. They were then pulled out from the device and tested. The depths of the dezincification, at which the microstructure images were taken from samples, were magnified 200 times by Nicon Eclipse Microscope using directly Clemex Vision Lite software.

Experiments were performed within the scope of the dezincification test standard [8]. The Nuve NB20 Water Bath device that was used is shown in Fig. 5.

For the determination of beta and alpha phase ratios, all samples were kept in a solution at $25^{\circ} \mathrm{C}$ $\left[60 \mathrm{~g}\left(\mathrm{NH}_{4}\right)_{2} \mathrm{~S}_{2} \mathrm{O}_{8}+50 \mathrm{ml} \mathrm{H} \mathrm{O}_{2}+700 \mathrm{ml} \mathrm{H} \mathrm{H}_{2} \mathrm{O}\right]$ for $45 \mathrm{~s}$. Beta and alpha phase ratios were measured by Nicon Eclipse microscope using directly Clemex Vision Lite software. 


\section{Results and discussion}

\subsection{Chemical composition test results of alloy}

Properties of CW625N (CuZn35Pb1) alloy determined according to the CEN/TS 13388 standard are shown in Table I. The chemical composition values of the twelve test samples are shared in Table III.

The element values of CW625N standard in Table I and the spectral analysis results of Table III are compared and all test samples are detected within scope of standard.

\subsection{Mechanical testing - hardness test results}

The measured hardness results of the samples are shared in Table IV. The surface hardness of heat treated samples are more than that of non-heat treated samples. The forging pressures are different while the forging temperature is the same for all samples. Samples forged at 90 bar pressure are detected to be harder than samples forged at 70 bar.

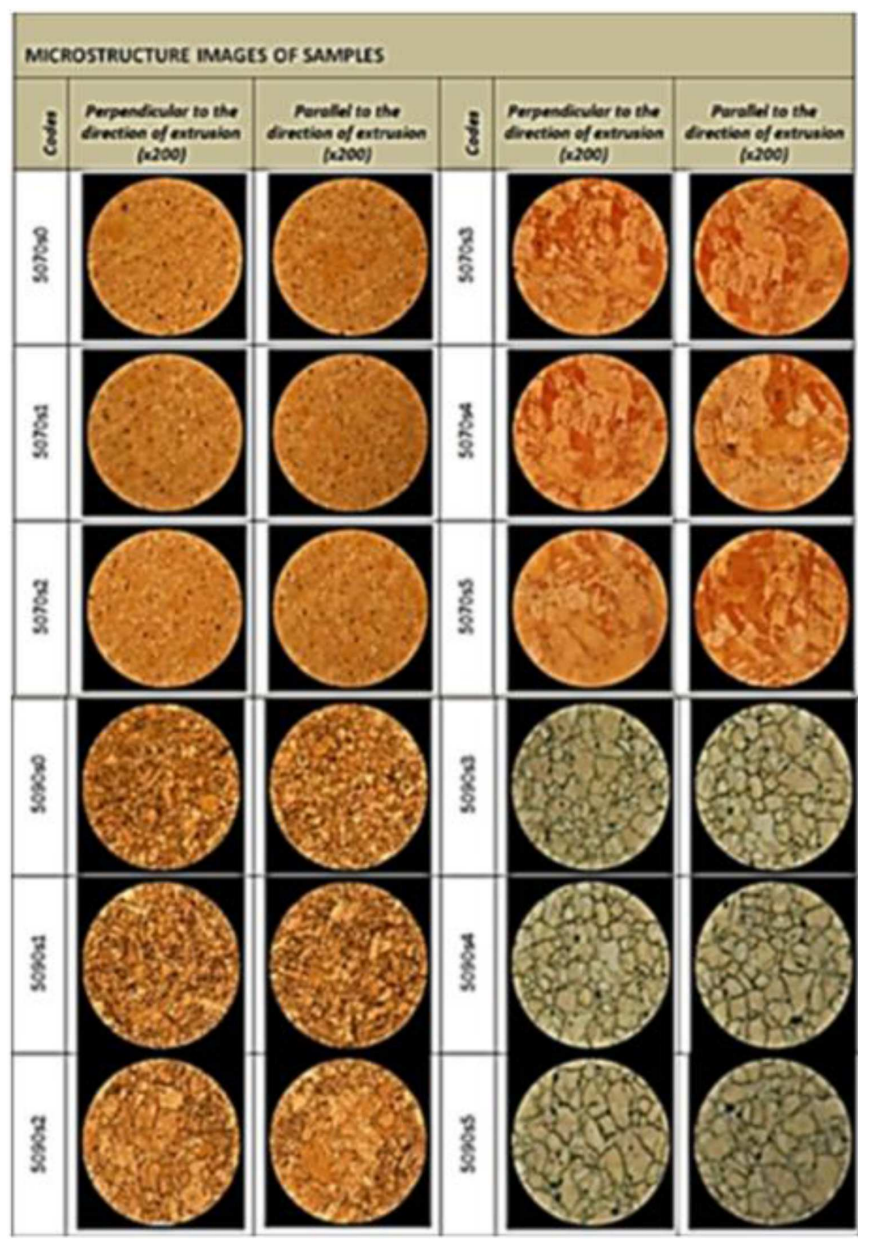

Fig. 6. Microstructure images.

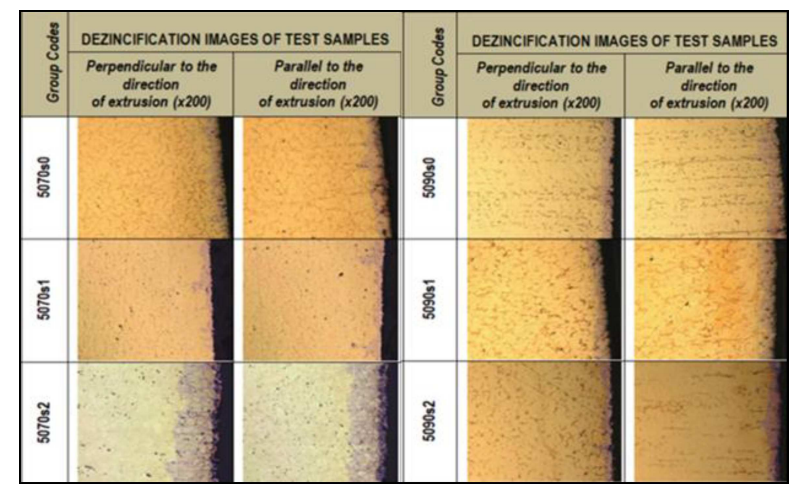

Fig. 7. Result images of dezincification depth which was first time heat treated.



Fig. 8. Result images of dezincification depth which was non-heat treated.

\subsection{Microstructure test results}

The microstructure and grain size of the samples are examined in this article. Microstructure images of samples, magnified 200 times, are shown in Table V. In addition, particle sizes along perpendicular and parallel to the direction of extrusion were measured. The particle sizes of the samples are shown in Fig. 6.

The metallographic examination, the particle size of the heat treated samples (samples 5070s0, 5070s1, 5070s2, 5090s0, 5090s1, and 5090s2) are smaller than the others. Direct effect of forging pressure on grain size in microstructure was observed. Increase of the forging pressure caused the grain size to grow.

\subsection{Dezincification testing results}

According to the TS EN ISO 6509-1 standard dezincification depths should be examined along perpendicular and parallel to the direction of extrusion. Respectively, it should be $100 \mu \mathrm{m}$ and $200 \mu \mathrm{m} \mathrm{[8]}$.

Within the scope were prepared and measured all samples for testing. The results are shown in Table VI.

The microscope images of the dezincification results are shared in Figs. 7 and 8. 


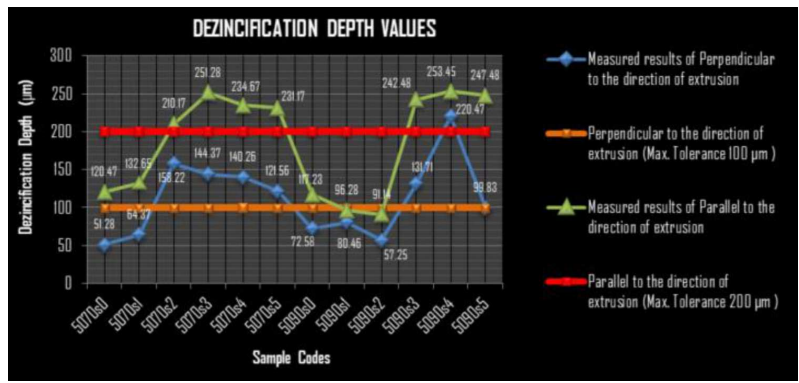

Fig. 9. Dezincification depth values are compared in standard [8].

TABLE VII

Beta grain size, beta and alpha phase ratio of test samples.

\begin{tabular}{c|c|c|c|c|c}
\hline \hline \multirow{2}{*}{$\begin{array}{c}\text { Group } \\
\text { Codes }\end{array}$} & \multicolumn{2}{|c|}{ Beta grain size } & \multicolumn{3}{|c}{ Beta and alpha phase ratio } \\
\cline { 2 - 6 } & $\begin{array}{c}\text { Min. } \\
\text { value } \\
{[\mu \mathrm{m}]}\end{array}$ & $\begin{array}{c}\text { Max. } \\
\text { value } \\
{[\mu \mathrm{m}]}\end{array}$ & $\begin{array}{c}\text { Beta } \\
\text { phase } \\
\text { ratio [\%] }\end{array}$ & $\begin{array}{c}\text { Alpha } \\
\text { phase } \\
\text { ratio [\%] }\end{array}$ & $\begin{array}{c}\text { Total } \\
\text { fields }\left[\mu \mathrm{m}^{2}\right]\end{array}$ \\
\hline 5070s0 & 0.03 & 7.12 & 6.34 & 93.66 & 190131.55 \\
$5070 \mathrm{~s} 1$ & 0.04 & 7.54 & 6.12 & 93.88 & 190131.55 \\
$5070 \mathrm{~s} 2$ & 0.07 & 7.32 & 9.72 & 90.28 & 190131.55 \\
$5090 \mathrm{~s} 0$ & 0.04 & 7.73 & 6.28 & 93.72 & 190131.55 \\
$5090 \mathrm{~s} 1$ & 0.04 & 7.84 & 6.47 & 93.53 & 190131.55 \\
$5090 \mathrm{~s} 2$ & 0.06 & 7.26 & 6.11 & 93.89 & 190131.55 \\
$5070 \mathrm{~s} 3$ & 0.03 & 12.73 & 9.67 & 90.33 & 190131.55 \\
$5070 \mathrm{~s} 4$ & 0.03 & 12.48 & 9.18 & 90.82 & 190131.55 \\
$5070 \mathrm{~s} 5$ & 0.06 & 13.11 & 9.54 & 90.46 & 190131.55 \\
$5090 \mathrm{~s} 3$ & 0.04 & 13.45 & 9.28 & 90.72 & 190131.55 \\
$5090 \mathrm{~s} 4$ & 0.06 & 13.26 & 9.73 & 90.27 & 190131.55 \\
$5090 \mathrm{~s} 5$ & 0.05 & 12.75 & 9.65 & 90.35 & 190131.55
\end{tabular}

TABLE VIII

Dezincification depth values of second time heat treated samples perpendicular and parallel to the direction of extrusion.

\begin{tabular}{c|c|c|c|c}
\hline \hline \multirow{4}{*}{$\begin{array}{c}\text { Group } \\
\text { codes }\end{array}$} & \multicolumn{3}{|c}{$\begin{array}{c}\text { Dezincification depth }[\mu \mathrm{m}] \\
\text { (cooled in calm air and heat treated twice) }\end{array}$} \\
\cline { 2 - 5 } & \multicolumn{2}{|c|}{$\begin{array}{c}\text { Perpendicular } \\
\text { (max. tol. } 100 \mu \mathrm{m})\end{array}$} & \multicolumn{2}{c}{$\begin{array}{c}\text { Parallel } \\
\text { (max. tol. } 200 \mu \mathrm{m})\end{array}$} \\
\cline { 2 - 5 } & $\begin{array}{c}\text { Min. } \\
\text { value }\end{array}$ & $\begin{array}{c}\text { Max. } \\
\text { value }\end{array}$ & $\begin{array}{c}\text { Min. } \\
\text { value }\end{array}$ & $\begin{array}{c}\text { Max. } \\
\text { value }\end{array}$ \\
\hline 5070s2-1 & 9.23 & 33.48 & 20.16 & 65.37
\end{tabular}

TABLE IX

Beta grain size, beta and alpha phase ratio of test samples for heat treated twice sample.

\begin{tabular}{c|c|c|c|c|c}
\hline \hline \multirow{2}{*}{$\begin{array}{c}\text { Group } \\
\text { Codes }\end{array}$} & \multicolumn{2}{|c|}{ Beta grain size } & \multicolumn{3}{c}{ Beta and alpha phase ratio } \\
\cline { 2 - 6 } & $\begin{array}{c}\text { Min. } \\
\text { value } \\
{[\mu \mathrm{m}]}\end{array}$ & $\begin{array}{c}\text { Max. } \\
\text { value } \\
{[\mu \mathrm{m}]}\end{array}$ & $\begin{array}{c}\text { Beta } \\
\text { phase } \\
\text { ratio [\%] }\end{array}$ & $\begin{array}{c}\text { Alpha } \\
\text { phase } \\
\text { ratio [\%] }\end{array}$ & $\begin{array}{c}\text { Total } \\
\text { fields }\left[\mu \mathrm{m}^{2}\right]\end{array}$ \\
\hline 5070s2-1 & 0.03 & 5.78 & 4.01 & 95.99 & 190131.55
\end{tabular}

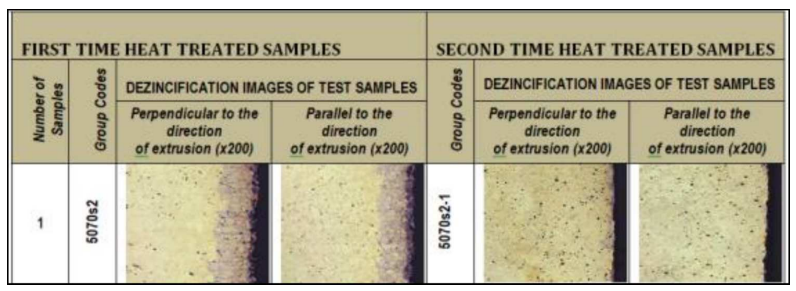

Fig. 10. Dezincification depth images of first and second heat treated sample are compared.

The curves of the dezincification depth values of each sample were obtained. The results of the samples were compared with the maximum and minimum of scope value of standard. The comparison graph of the extracted curves are shown in Fig. 9.

Beta grain size values of 12 samples and beta phase ratio test results in the alloy are shown in Table VII.

Dezincification depth value of one of the twelve samples, which are heat treated, is not found to be within the standard. In this study, heat treatment effects, as well as different hot forging pressure parameters are examined. Therefore, one unsuitable sample within the scope of standard was subject to $\left(550^{\circ} \mathrm{C}\right.$ and $2.5 \mathrm{~h}$ parameters) heat treatment twice.

The results of the second heat treatment application are shown in Table VIII. One can determined that the dezincification depth of the 5070s2 sample was within the scope of the desired standard.

The high percentage of beta phase in the alloy causes low dezincification resistance. From the analysis of the results from Table IX, it can be seen that the second time heat treatment allowed to reduce beta phase size and beta phase percentage.

Resulting images of the dezincification depth of the sample, which was twice heat treated, are shown in Fig. 10.

\section{Conclusions}

In this paper we have investigated the effect of hot forging pressure and heat treatment on given samples. They were formed by keeping at forging temperature of $750^{\circ} \mathrm{C}$, and at two different values (70 Bar and 90 Bar) in the forging pressure. The parameters and heat treatment were applied also to the CW625N alloy. The effect on the dezincification resistance values was investigated. In addition, the effect of the applied parameters on the hardness, microstructure and grain size in the microstructure was examined. In this direction

- The surface hardness values of heat treated samples are higher than that of non-heat treated samples. In addition to stabilizing the microstructure, heat treatment causes surface hardness. 
- Heat treatment reduces the grain size, beta phase ratio, and dezincification depth within the microstructure. The second heat treatment of the 5070s 2 sample reduced the beta phase ratio from $9.72 \%$ to $4.01 \%$. Heat treatment is a process that directly increases the dezincification resistance.

- Direct effect of forging pressure differences on dezincification resistance was not found. Increase of forging pressure was seen as a parameter that slowed down the microstructure to become fully stable. Direct effect of forging pressure on grain size in microstructure was observed. The forging pressure increase caused the grain size to grow.

\section{Acknowledgments}

We thank Pireks Bakir Alaşimlari San. Ve Tic. A.Ş. who provided the bars for test samples, Kale Musluk San. Ve Tic. A.S. where hot forging of test samples was done, Sarbak Metal Sarbak Metal Tic. Ve San. A.Ş. where tests of dezincification, beta grain size and beta phase ratio determination occurred.

\section{References}

[1] M. Tang, P. Sinsheimer, E. Sarver, J. Parks, M. Edwards, Corrosion 75, 865 (2019).

[2] Copper Alloys - Early Applications and Current Performance - Enhancing Process, Ed. L. Collini, InTech 2012, p. 15.

[3] R.N. Caron, "Copper Alloys: Thermal and Thermomechanical Processing", Encyclopedia of Materials: Science and Technology, 2nd ed., 2001, p. 1668.

[4] Revised by A. Cohen, "Heat Treating of Copper Alloys", in: ASM Handbook, Vol. 4, ASM Int., 1991.

[5] CEN/TS 13388:2015 Copper and Copper Alloys Compendium of compositions and products.

[6] TS EN 12164:2016 Copper and Copper Alloys — Rod for free machining purposes standards.

[7] TS EN 12420:2014 Copper and Copper Alloys Forgings.

[8] TS EN ISO 6509-1 Corrosion of metals and alloys Determination of dezincification resistance of copper alloys with zinc - Part 1: Test method.

[9] in: ASM Handbook, Eds. R.N. Caron, R.G. Barth, D.E. Tyler Vol. 9, ASM Int., 2004, p. 775. 